Gazi University
Journal of Science
http://dergipark.gov.tr/gujs

\title{
Calocybe persicolor, A New Record for the Turkish Mycota
}

\author{
$\operatorname{Ilgaz}_{\text {AKATA }}^{1, *(D)}$, Ilker BUYUK ${ }^{1(D)}, \operatorname{Deniz~ALTUNTAS~}^{1}(\mathbb{D})$, Ertuğrul SESLI $^{2}(\mathbb{D})$ \\ ${ }^{1}$ Ankara University, Faculty of Science, Department of Biology, Ankara, Turkey \\ ${ }^{2}$ Trabzon University, Fatih Education Faculty, Department of Biology, Trabzon, Turkey
}

\section{Highlights}

- C. persicolor was the first time reported from Turkey and hence makes an important contribution to the Turkish mycota.

- Both conventional and molecular methods were used for identification.

- The first ITS sequence data belongs to Calocybe persicolor was uploaded to the GenBank from Turkey.

\section{Article Info}

Received: 06/02/2019 Accepted: $23 / 05 / 2019$

\section{Keywords}

Calocybe persicolor Ankara

Molecular phylogeny New record

\begin{abstract}
The aim of this study is to identify fungal samples from Ankara (Turkey). Identification of the samples was made according to conventional and molecular methods (ITS region of the rDNA). Based on the high sequence similarity of the new record (hereafter will be referred to as 'Ank Akata \& Altuntaş 166') with Calocybe persicolor (Fr.) Singer, the relevant agaric is considered to be $C$. persicolor. This result is also supported by the morphological data and proves the presence and distribution of this species in Turkey.
\end{abstract}

\section{INTRODUCTION}

Calocybe, a small genus of the family Lyophyllaceae (Agaricales), includes approximately 40 widely distributed species [1]. Members of the genus are mainly characterized by the tricholomatoid fruiting body, conical to convex or plane pileus, emarginate and crowded lamellae, cylindrical stipe, cylindrical to clavate and siderophilous basidia, whitish to creamy spore print, ellipsoid basidiospores and usually clamped hyphae [2].

Calocybe persicolor (Fr.) Singer appears in late summer and fall growing on soil in grassy meadows, parks, less frequently in woods. Although it is an uncommon species, C. persicolor have been reported in Europe, Asia, and America [2].

According to the checklist on Turkish macromycota [3], four Calocybe species (Calocybe carnea (Bull.) Donk, C. chrysenteron (Bull.) Singer, C. gambosa (Fr.) Donk and C. ionides (Bull.) Donk were collected but, no information has been reported about the presence and distribution of $C$. persicolor in Turkey up to date [3-9]. The present study proves the presence of $C$. persicolor in Turkey and aims to make a contribution to Turkish mycota. 


\section{EXPERIMENTAL}

\subsection{Morphological study}

Fungal samples were collected from Ankara University Tandoğan Campus (Ankara) on September 2, 2018. In the research area, relevant macroscopic and ecological features of the fruiting bodies were registered. Routine macroscopic and microscopic investigations were performed with the help of the literature [10,11] in our laboratory. The identified samples were deposited at Ankara University Herbarium (ANK).

\subsection{Molecular study}

DNA Isolation-The genomic DNA was extracted according to the modified CTAB method [12]. NanoDrop ND-Lite was used to measure DNA concentration and purity of the samples.

Table 1. GenBank accession numbers of the ITS sequences belonging to the 17 fungi specimens used in this study

\begin{tabular}{|l|l|l|l|}
\hline Fungi species & GenBank number (ITS) & Geographical origin & Reference \\
\hline Leucocybe connata & MG953997 & Canada & Unpublished \\
\hline Leucocybe candicans & KJ681027 & Spain & {$[13]$} \\
\hline Tricholomella constricta & JF907769 & Italy & {$[14]$} \\
\hline Tephrocybe rancida & EU669250 & USA & Unpublished \\
\hline Tephrocybe ambusta & AF357058 & Switzerland & {$[15]$} \\
\hline Tephrocybe anthracophila & KU058523 & Australia & {$[16]$} \\
\hline Tephrocybe atrata & AF357053 & Switzerland & {$[15]$} \\
\hline $\begin{array}{l}\text { Asterophora } \\
\text { lycoperdoides }\end{array}$ & KR673545 & South Korea & {$[17]$} \\
\hline $\begin{array}{l}\text { AnkAkata\&Altuntaş 166 } \\
\text { Calocybe persicolor) }\end{array}$ & SUB5067264 & Turkey & Current study \\
\hline Asterophora parasitica & MG890393 & USA & Unpublished \\
\hline $\begin{array}{l}\text { Lyophyllum decastes } \\
\text { Lyophyllum semitale }\end{array}$ & KM572548 & Northern & {$[18]$} \\
\hline Calocybe decolorata & NR156302.1 & Franoscandia & {$[19]$} \\
\hline Calocybe obscurissima & AF357031 & China & Unpublished \\
\hline Calocybe persicolor & AF357026 & Switzerland & {$[15]$} \\
\hline Cortinarius anisatus & NR131788 & Switzerland & {$[15]$} \\
\hline Amanita muscaria & AB015700 & Sweden & {$[20]$} \\
\hline
\end{tabular}

PCR Amplification and Sequencing - The ITS region of the rDNA was amplified using ITS1 and ITS4 primers [22,23]. The PCR was performed in $50 \mu 1$ volumes containing $10 \times$ buffer, 1 -unit Taq DNA polymerase (Promega, Madison, Wisconsin), $200 \mu \mathrm{M}$ dNTPs, $2 \mathrm{mM} \mathrm{MgCl}_{2}$, and 10 pmol of both primers, ITS 1 and ITS4. PCR amplification was performed in a Biometra TProfessional Standard thermal cycler (Biometra, $\mathrm{GmbH}$, Germany) with the following thermal cycling conditions: one cycle of $94^{\circ} \mathrm{C}$ for $2 \mathrm{~min}$, 35 cycles of $94^{\circ} \mathrm{C}$ for $30 \mathrm{~s}, 55^{\circ} \mathrm{C}$ for $1 \mathrm{~min}$, and $72^{\circ} \mathrm{C}$ for $1 \mathrm{~min}$, and a final extension step of $8 \mathrm{~min}$ at $72^{\circ} \mathrm{C}$. The amplification products were analyzed by electrophoresis in $1.2 \%$ agarose gel containing ethidium bromide, and the product sizes were determined using a nucleotide size marker (100 bp ladder; Fermentas, Vilnius, Lithuania). The PCR products were sequenced with a BigDye cycle sequencing kit (Applied Biosystems, Foster City, California) using an ABI 3130XL genetic analyzer (Applied Biosystems).

Sequence Analysis - The amplified fragments were sequenced and the ITS gene sequences from several other fungal species were obtained from GenBank to compare with the 'Ank Akata \& Altuntaş 166' (Supplementary Table 1). The DNA sequences were aligned and assembled using Multiple Sequence Comparison by Log-Expectation (MUSCLE) by Geneious R9 [24]. Molecular phylogenetic analyses were 
performed using the maximum likelihood method based on the Tamura 3-parameter substitution model via MEGA7 software [25]. One thousand bootstrap replicates were performed [26].

\section{RESULTS AND DISCUSSION}

The systematics of the new record was in accordance with Kirk et al. [1] and MycoBank (accessed 02.2019) [27]. Short descriptions and the ecology of the species were given with the field photos. Through phylogenetic analysis, we revealed two distinct clades as well as an outgroup. The major clade (Clade 1) included fungi species from the genus Leucocybe, Tricholomella, Asterophora, Lyophyllum, and Tephrocybe, while the minor clade (Clade 2) contained species only from the genus Calocybe together with 'Ank Akata \& Altuntaş' with a bootstrap value of $94 \%$. On the other hand, Cortinarius anisatus H. Lindstr., Kytöv. \& Niskanen and Amanita muscaria (L.) Lam. were branched far from the other fungi species and generated an outgroup as expected with a bootstrap value of $100 \%$. Moreover, the phylogenetic tree based on ITS sequences provided evidence for almost $99 \%$ similarity of the new record with C. persicolor.

\subsection{Description of the newly reported species}

Lyophyllaceae Jülich

Calocybe persicolor (Fr.) Singer (1962), (Figures 1, 2)

Syn.: Agaricus persicolor Fr. $(1874)=$ Tricholoma persicolor $($ Fr. $)$ Sacc. $(1887)=$ Lyophyllum persicolor (Fr.) Malençon \& Bertault (1975).

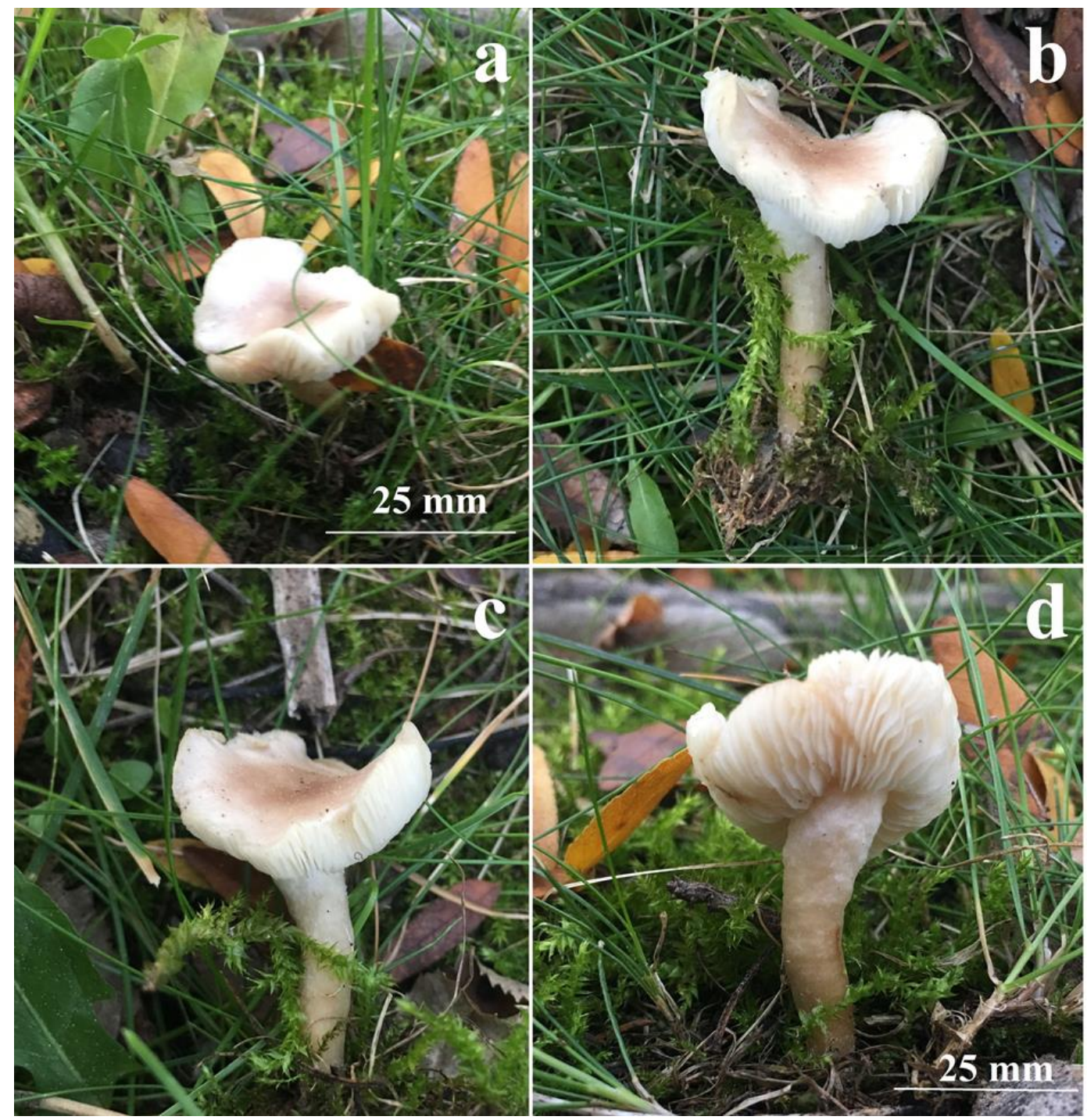

Figure 1. Calocybe persicolor: a-d. basidiomata 


\section{Macroscopic and microscopic characteristics}

Pileus 20-25 mm; convex when young, then plane with involute margin. Surface cream to pinkish with a light brownish tinge, dry, smooth but pruinose towards to margin. Lamellae white, emarginate and crowded. Stipe 30-35 $\times 5 \mathrm{~mm}$, cylindrical, concolorous with pileus somewhat paler, fibrillose. Flesh thin and white with a pinkish tinge. Taste farinaceous. Odor unpleasant. Basidia 15.5-17.5 $\times$ 4.5-6 $\mu \mathrm{m}$, clavate, four-spored, with siderophilous granules and basal clamped. Basidiospores 4.5-6 $\times$ 2-3 $\mu \mathrm{m}$, smooth, hyaline and ellipsoid. Cystidia absent. Pileipellis a cutis, consisting of irregular and swollen hyphae, some septa with clamps.

Ecology: Uncommon, summer to autumn, in meadows, parks, garden, on soil, among grasses [11].

Specimen examined: TURKEY - Ankara: Ankara University Tandoğan campus, under Judas-tree (Cercis siliquastrum L.), among grasses, $860 \mathrm{~m}, 39^{\circ} 56^{\prime} 04^{\prime \prime} \mathrm{N}, 32^{\circ} 50^{\prime} 01^{\prime \prime} \mathrm{E}, 02.09 .2018$, ANK Akata \& Altuntaş 166.



Figure 2. Calocybe persicolor: $a$, b. basidia. c. basidiospores $d$. pileipellis

The phylogenetic tree which was drawn based on ITS sequences branched into three groups, Clade A and Clade B, and an outgroup (Figure 3). The outgroup included Cortinarius anisatus and Amanita muscaria as it was expected. The Clade B was seen to be the largest group which included the members of Asterophora, Leucocybe, Lyophyllum, Tricholomella and Tephrocybe (Figure 3). The Clade A was only comprised of Calocybe members and Ank Akata \& Altuntaş 166 as well. In addition, C. persicolor showed 99\% similarity with Ank Akata \& Altuntaş 166.

C. persicolor is characterized by its pink to pinkish brown, convex to plane pileus, cylindrical stipe, whitish flesh, four-spored and clavate basidia; elliptic, smooth and hyaline basidiospores. C. carnea is a close 
species but differs with bright pink to pinkish brown fruiting bodies [10]. As the morphological data is not sufficient for the precise identification of fungi, the use of sequence data from conserved DNA regions such as ITS is considered to be an important tool in taxonomy and systematics since last three decades [28,29]. Moreover, ITS is the most common DNA barcoding marker and thus provides an important source for the researchers to make comparisons of data obtained from their own studies with the one found in the GenBank database. For this reason, we used ITS region for molecular identification and the phylogenetic analysis made based on the ITS regions revealed almost 99\% genetic similarity between Calocybe persicolor and the new record (GenBank ID: AF357026) (Figure 3).

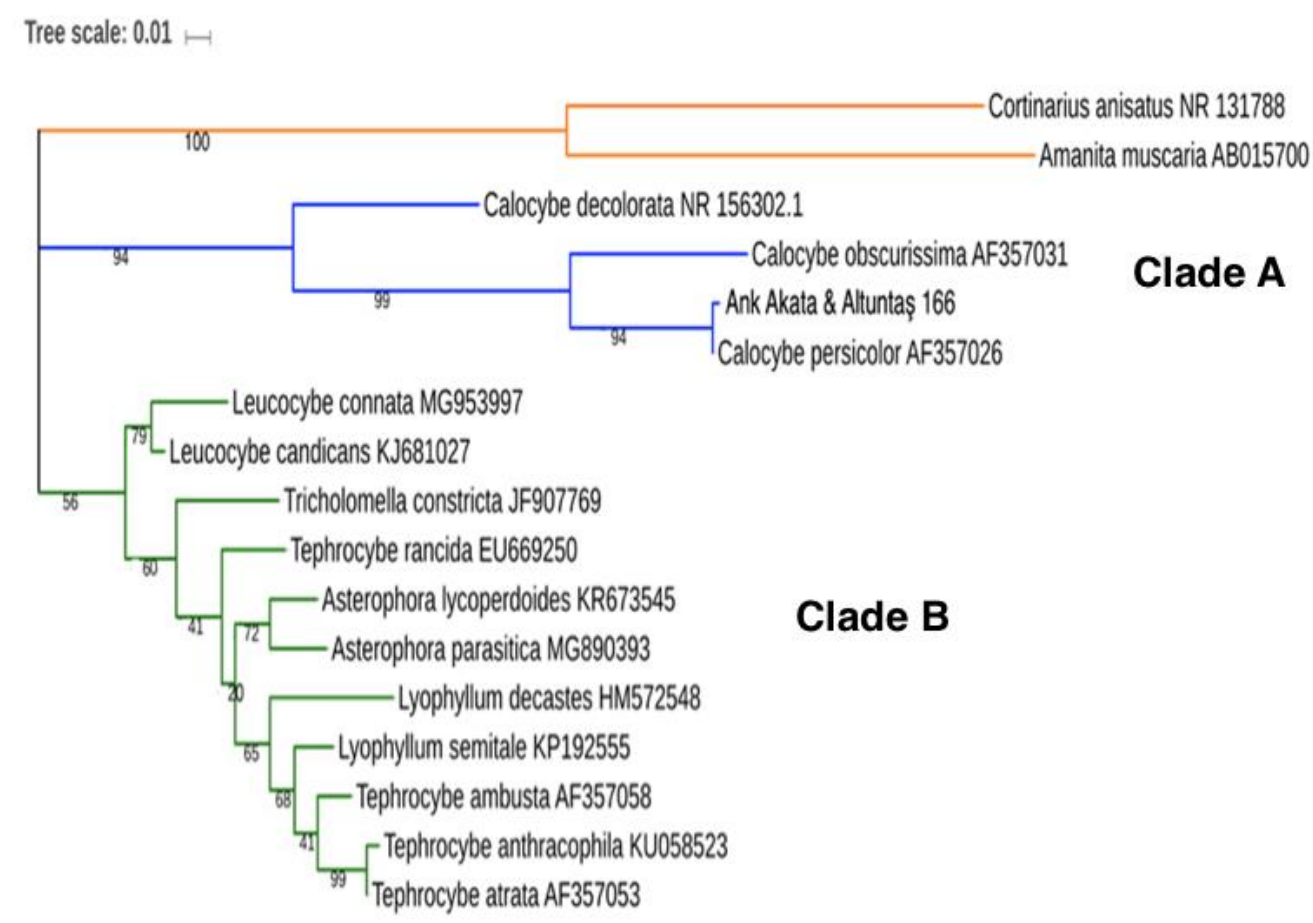

\section{Outgroup}

Figure 3. The maximum likelihood tree showing the genetic relationships between 17 fungi based on the nuclear ITS region. Bootstrap values from 1000 bootstrap replicates were given above the branches. All sequences were retrieved from GenBank except for Ank Akata \& Altuntaş 166. Cortinarius anisatus and Amanita muscaria were used as outgroup samples.

\section{ACKNOWLEDGMENTS}

We thank the Ankara University Research Fund (Project no: 18B0430001) for financial support.

\section{CONFLICTS OF INTEREST}

No conflict of interest was declared by the authors.

\section{REFERENCES}

[1] Kirk, P.M., Cannon, P.F., Minter, D.W. and Stalpers, J.A., Dictionary of the fungi 10 nd ed., Wallingford: CAB International, (2008).

[2] Knudsen, H. and Vesterholt, J., Funga Nordica Agaricoid, Boletoid and Cyphelloid Genera, Nordsvamp, Copenhagen, Denmark, (2008).

[3] Sesli, E. and Denchev, C.M., "Checklists of the myxomycetes, larger ascomycetes, and larger basidiomycetes in Turkey", Mycotaxon, 106: 65-67, (2008). 
[4] Akata, I., "Macrofungal Diversity of Belgrad Forest (İstanbul)". Kastamonu Üniv. Orman Fak. Derg., 17(1): 150-164, (2017).

[5] Akata, I. and Uzun, Y., "Macrofungi determined in Uzungöl Nature Park (Trabzon)", Trakya Univ. J. Nat. Sci., 18(1): 15-24, (2017).

[6] Akata, I., Altuntaş, D. and Kabaktepe Ş. "Fungi Determined in Ankara University Tandoğan Campus Area (Ankara-Turkey)", Trakya Univ. J. Nat. Sci., 20(1): 47-55, (2019).

[7] Doğan, H.H. and Kurt, F., "New macrofungi records from Turkey and macrofungal diversity of Pozant1-Adana", Turk. J. Bot., 40: 209-217, (2016).

[8] Sesli, E. and Vizzini, A., "Two new Rhodocybe species (sect. Rufobrunnea, Entolomataceae) from the East Black Sea coast of Turkey", Turk. J. Bot., 41: 200-210, (2017).

[9] Tırpan, E., Çöl, B., Şen, İ. and Allı, H., "Macrofungi of Datça Peninsula (Turkey)", Bio. Di. Con., 11(3): 90-98, (2018).

[10] Breitenbach, J. and Kränzlin, F., Fungi of Switzerland. Vol: 3, Boletes and Agarics 1. Part, Verlag Mykologia CH-6000 Luzern 9, Switzerland, (1991).

[11] Jordan, M., The Encyclopedia of Fungi of Britain and Europe, Frances Lincoln, London, (2004).

[12] Aras, S., Duran A. and Yenilmez G., "Isolation of DNA for RAPD analysis from dry leaf material of some Hesperis L. specimens", Plant Mol. Biol. Report., 21(4): 461-462, (2013).

[13] Alvarado, P., Moreno, G., Vizzini, A., Consiglio, G., Manjon, J.L. and Setti, L., “Atractosporocybe, Leucocybe and Rhizocybe: three new clitocyboid genera in the Tricholomatoid clade (Agaricales) with notes on Clitocybe and Lepista”, Mycologia, 107(1): 123-136, (2015).

[14] Osmundson, T.W., Robert, V.A., Schoch, V.A., Baker, L.J., Smith, A., Robich, G., Mizzan, L. and Garbelotto, M.M., "Filling Gaps in Biodiversity Knowledge for Macrofungi: Contributions and Assessment of an Herbarium Collection DNA Barcode Sequencing Project”, Plos one, 8(4): e62419, (2013).

[15] Hofstetter, V., Clémençon, H., Vilgalys, R. and Moncalvo, J.M., "Phylogenetic analyses of the Lyophylleae (Agaricales, Basidiomycota) based on nuclear and mitochondrial rDNA sequences", Mycol. Res., 106(9): 1043-1059, (2002).

[16] Sánchez- García, M. and Matheny, P.B., "Is the switch to an ectomycorrhizal state an evolutionary key innovation in mushroom- forming fungi? A case study in the Tricholomatineae (Agaricales)", Evolution, 71(1): 51-65, (2016).

[17] Kim, C.S., Jo, J.W., Kwag, Y.N., Sung, G.H., Lee, S., Shin C.H. and Han, S.K., "Mushroom Flora of Ulleung-gun and a Newly Recorded Bovista Species in the Republic of Korea", Mycobiology, 43(3): 239-257, (2015).

[18] Larsson, E. and Sundberg, H., "Lyophyllum shimeji, a species associated with lichen pine forest in northern Fennoscandia", Mycoscience, 52: 289-295, (2011).

[19] Bellanger, J.M., Moreau, P.A., Corriol, G., Bidaud, A., Chalange, R., Dudova, Z., and Richard, F., "Plunging hands into the mushroom jar: a phylogenetic framework for Lyophyllaceae (Agaricales, Basidiomycota)", Genetica, 43(2): 169-94, (2015). 
[20] Kytövuori, I., Niskanen, T., Liimatainen, K. and Lindström, H., "Cortinarius sordidemaculatus and two new related species, $C$. anisatus and $C$. neofurvolaesus, in Fennoscandia (Basidiomycota, Agaricales)", Karstenia, 45: 33-49, (2005).

[21] Oda, T., Tanaka, C. and Tsuda M., "Molecular phylogeny of Japanese Amanita species based on nucleotide sequences of the internal transcribed spacer region of nuclear ribosomal DNA", Mycoscience, 40(1): 57-64, (1999).

[22] White, T.J., Bruns, T., Lee, S. and Taylor J., "Amplification and direct sequencing of fungal ribosomal RNA genes for phylogenetics", Pp. 315-322 in PCR Protocols: A Guide to Methods and Applications, eds. M. A. Innis, D. H. Gelfand, J. J. Sninsky, and T. J. White. New York: Academic Press, (1990).

[23] Hamzaoğlu, E., Koç M. and Buyuk I., "Bolanthus sandrasicus sp. nov. (Caryophyllaceae) from Turkey”, Nord. J. Bot., 35: 563-568, (2017).

[24] Kearse, M., Moir, R., Wilson, A., Stones-Havas, S., Cheung, M., Sturrock, S., Buxton, Cooper, A., Markowitz, S., Duran, C., Thierer, T., Ashton, B., Meintjes, P. and Drummond, A., "Geneious Basic: An integrated and extendable desktop software platform for the organization and analysis of sequence data", Bioinformatics, 28: 1647-1649, (2012).

[25] Tamura, K., D, Peterson, N, Peterson, G, Stecher, M, Nei. and S, Kumar., "MEGA5: Molecular evolutionary genetics analysis using maximum likelihood, evolutionary distance, and maximum parsimony methods". Mol. Biol. Evol., 28: 2731-2739, (2011).

[26] Felsenstein, J., "Confidence limits on phylogenies: An approach using the bootstrap", Evolution, 39: 783-791, (1985).

[27] Internet: Calocybe persicolor, In Mycobank Online. http://www.mycobank.org/BioloMICS.aspx?Table=Mycobank\&Rec=211432\&Fields=All, (2013).

[28] Baldwin, B.G., "Phylogenetic utility of the internal transcribed spacers of nuclear ribosomal DNA in plants: An example from the Compositae", Mol. Phylogenetics Evol., 1(1): 3-16, (1992).

[29] Raja, H.A., Miller, A.N., Pearce, C.J. and Oberlies, N.H., "Fungal Identification Using Molecular Tools: A Primer for the Natural Products Research Community", J. Nat. Prod., 80(3): 756-770, (2017). 